\title{
Process and Properties Study of Porous Thermal Insulation Building Materials Based on Walnut Shell
}

\author{
Ying-Liang TIAN ${ }^{1, a}$, Si-Qi $\mathrm{LI}^{1,} \mathrm{~b}^{*}$, Chang-Wei XU², Jin-Wei LI ${ }^{1}$, Shi-Bing SUN ${ }^{1}$, \\ Hong $\mathrm{QI}^{2}$, Cun-Xi MA ${ }^{3}$, Ming-Pu CAO ${ }^{3}$ \\ ${ }^{1}$ Beijing University of Technology, Beijing, China 100124 \\ 2 Shenyang Jianzhu University, Shenyang, China 110168 \\ ${ }^{3}$ Zhengzhou Dengdian Kecheng New Materials CO., LTD, Zhengzhou, China 452480 \\ aboli106@126.com, b15083466567@163.com \\ ${ }^{*}$ Corresponding author
}

Keywords: Porous Thermal Insulation Materials, High Temperature Foaming, Materials Properties, Microscopic Morphology.

\begin{abstract}
In this paper, shale and feldspar were regarded as matrix materials and sillcon carbide was added as foaming agent. After a quality ratio of walnut shell was mixed with as pore-forming agent,porous insulation materialswere made through high temperature foaming. The firing curve was developed by studying the thermal history. XRD and micro-morphology were used to study the effects of the amount of walnut shell on the density, thermal conductivity and mechanical properties of the products. The results show that when the amount of walnut shell was $10 \%$, the sample density was $180 \mathrm{~kg} / \mathrm{m}^{3}$, and the flexural strength and compressive strength could reach $1.031 \mathrm{MPa}$ and $0.862 \mathrm{MPa}$ respectively.Meanwhile, the thermal conductivity was $0.076 \mathrm{~W} /(\mathrm{m} \cdot \mathrm{K})$ and the water absorption could achieve $1.5 \%$. It is concluded that adding walnut shell has no effect on the crystallization of the sample, but the walnut shell couldreplace a part of raw materials, resulting in the increase of density and strength. At the same time, the appearance of miscellaneous stomata could be attributed to the addition of walnut shell, and the number of open pores increased, leading to the increase of water absorption and thermal conductivity.
\end{abstract}

\section{Introduction}

The walnut cultivated area in China ranks the top in the world. After walnut processing, substantive walnut shell is produced, and it will cause terrible resources waste if incinerated or discarded. In recent years, intensive study of comprehensive utilization of walnut shell was carried out, such as using walnut shell to prepare and extract brown pigment, xylose and active carbon. But the utilization and assimilation rate of walnut shell is extremely low [1,2]. The analysis on walnut shell composition (fixed carbon $15.03 \%$, ash $0.72 \%$, water $6.70 \%$, volatile matter $77.52 \%$ ) and industrial analysis on ingredient in tab. 1 show that walnut shell has high calorific value effect. In heating process, walnut shell will release heat quantity of about $2800-4500 \mathrm{Kcal} / \mathrm{kg}$, which is $40-60 \%$ of caloric power of coal. Thus walnut shell can serve as an organic fuel to substitute part of coal. They also could release heat in the sintering and molding of thermal insulation building materials, that may save more energy and protect environment [3-5].

Tab. 1 The main components of the shell $/ \%$

\begin{tabular}{cccccc}
\hline Nutshell & $\begin{array}{c}\text { Benzene-ethanol } \\
\text { extract }\end{array}$ & Cellulose & Hemicellulose & Lignin & Water \\
\hline walnut & $2.57 \pm 0.24$ & $26.40 \pm 0.05$ & $17.85 \pm 0.31$ & $43.70 \pm 0.57$ & $8.5 \pm 0.29$
\end{tabular}

In recent years, exterior wall exterior insulation system, as green constructional materials, required to be light, high-tensile, highly thermal-insulating and incombustible [6]. With high thermal insulation property and relatively low price, traditional organic heat insulating materials 
have occupied nearly $80 \%$ of the market. However, a series of frequent building fire makes more attention to fire prevention performance, and urges people to value application and development of inorganic thermal insulating materials [7]. As a light inorganic porosint, foaming ceramic has good mechanical property and heat-insulating property, and low cost of manufacture. Substantive static air is charged in pore gap, while the coefficient of thermal conductivity of air in closed state is only $0.023 \mathrm{~W} /(\mathrm{m} \cdot \mathrm{K})$, far below the heat conductivity of solid. So it can slow down heat flow and prevent transfer of heat from high temperature to low temperature, isolating influence from solar radiation and high temperature [8].

This paper takes shale, feldspar etc. as raw materials, adding sillcon carbide as foaming agent, and mixes a quality ratio of grinded walnut shell as a pore-forming agent to prepare porous inorganic material, which is light and thermal-insulating. The high temperature foaming to the raw materials mixture allows the walnut shell fully pyrolyzed inside the ceramic cavity by site occupancy, which can also cut down the use of coal. This paper explores formulation of raw materials and experimental processes such as fabrication process and thermal process, etc and analyzes crystalline phase and reification of sample.

\section{Experimental Process}

\section{Raw Materials}

Raw materials of ceramic base:shale was a sedimentary rock, containing heaps of detrital minerals and authigenic minerals (such as iron, aluminum, manganic oxide and hydrate), etc. in addition to clay minerals ( such as kaolinite, smectite, hydromica, beidellite, etc.). Raw material of solvent: feldspar. The oxide in fluxing agent minerals played the role of adorn silicate network, and could accelerate high temperature differentiation reaction. Foaming agent: sillcon carbide. Pore forming agent (internal combustion agent): wallnut shell was fractured by crusher, then sifted in electromotor, and the fractured walnut shell between 80-100 meshes was selected.

Tab. 2 Chemical composition of raw materials $/ \%$

\begin{tabular}{cccccccc}
\hline Materials & $\mathrm{SiO}_{2}$ & $\mathrm{Al}_{2} \mathrm{O}_{3}$ & $\mathrm{Fe}_{2} \mathrm{O}_{3}$ & $\mathrm{~K}_{2} \mathrm{O}$ & $\mathrm{CaO}$ & $\mathrm{MgO}$ & Other \\
\hline Mentougou shale & 57 & 23 & 7.7 & 0.9 & 1.6 & 8.4 & 1.4 \\
& & & & & & & \\
\hline Potassium feldspar & 67 & 17.8 & 0.05 & 7.6 & 0.5 & 0.6 & 6.4 \\
\hline
\end{tabular}

\section{Foaming Theory}

Utilizing the reaction between $\mathrm{SiC}$ and the free oxygenin minerals or $\mathrm{O}_{2}$ generated by $\mathrm{Fe}_{3} \mathrm{O}_{4}, \mathrm{SO}_{3}$, $\mathrm{SO}_{4}{ }^{2-}$ oxidative decomposition produce $\mathrm{CO}, \mathrm{CO}_{2}$, the reactionis as follows:

$$
\begin{gathered}
\mathrm{SiC}(\mathrm{s})+(3 / 2) \mathrm{O}_{2}(\mathrm{~g}) \rightarrow \mathrm{SiO}_{2}(\mathrm{~s})+\mathrm{CO}(\mathrm{g}) \\
\mathrm{SiC}(\mathrm{s})+2 \mathrm{O}_{2}(\mathrm{~g}) \rightarrow \mathrm{SiO}_{2}(\mathrm{~s})+\mathrm{CO}_{2}(\mathrm{~g})
\end{gathered}
$$

This reaction temperature is between $880^{\circ} \mathrm{C} \sim 1140^{\circ} \mathrm{C}$. To get substantive and stable bubbles requires reaction and deflation velocity of foaming agent being gentle and exactly locating in the softening temperature range of ceramic materials [8]. At high temperature, material base and foaming agent congruently melt with each other and react chemically to generate volatile gases. Due to high viscocity of material fusant, gas volatilization causes general bulging of material. With decrease of sintering temperature, the "pits" formed after gas volatilization in fusant are preserved and dense closed pores appeared in material, thereby forming porous and light structure $[9,10]$. 


\section{Preparation Technics}

Based on substantive experiments, formulation of foaming ceramic material is selected (\%): shale $89.7 \%$, feldspar $6.2 \%$, SiC $4.1 \%$, ball-milling the mixed raw materials with water to certain fineness. Spray dry a part of slurry for granulation. Mix and whip evenly granulation materials and cracked walnut shell, then put them in fireproof mould to be sintered and foamed at high temperature in kiln. Finally anneal and incise them. The measure of samples used for testing coefficient of thermal conductivity and water absorption was $300 \mathrm{~mm} \times 300 \mathrm{~mm}$, and the thickness was $30-40 \mathrm{~mm}$. The size of compressive strength and flexural strength test was $100 \mathrm{~mm} \times 100 \mathrm{~mm} \times 50 \mathrm{~mm}$ and $250 \mathrm{~mm} \times$ $80 \mathrm{~mm} \times 40 \mathrm{~mm}$ respectively.

\section{Detection Method}

Density of insulation materials was according to Archimedean measured method, and the water absorption was measured by boiling method. Measuringmechanical properties referenced of GB/T 5486-2008 <Test methods for inorganic rigid thermal insultion>. The coefficient of thermal conductivity was according to GB/T 10295-2008 <Thermal insulation-Determination of steady-state thermal resistance and related properties-Heat flow meter apparatus $>$.The Bruker D8 X-ray was used to analyze the phase composition of sintered products. The TG-DSC thermal analysis was performed on a Netzsch STA409 PC/PG thermoanalyzer. Sintering image was analyzed by SJY image sintering point tester.

\section{Results and Discussion}

\section{Firing System Development}

Make TG-DSC analysis for walnut shell, with pyrolysis temperature scope being $30-800^{\circ} \mathrm{C}$, heating rate being $10^{\circ} \mathrm{C} / \mathrm{min}$, and atmosphere being air. Internal temperature gradient of the samples caused by sample stacking was ignored, then it could be regarded that thermal decomposition of sample occurs in dynamics state. In the pyrolysis process, the recording instrument automatically recorded the change of sample quality and heat quantity with time and temperature to get thermogravimetric curve-TG and differential thermal curve-DSC. Experimental result was shown in fig. 1: it was observed that pyrolyzed part was approximately divided into three stages of dehydration drying, flash pyrolysis and slow decompounding.

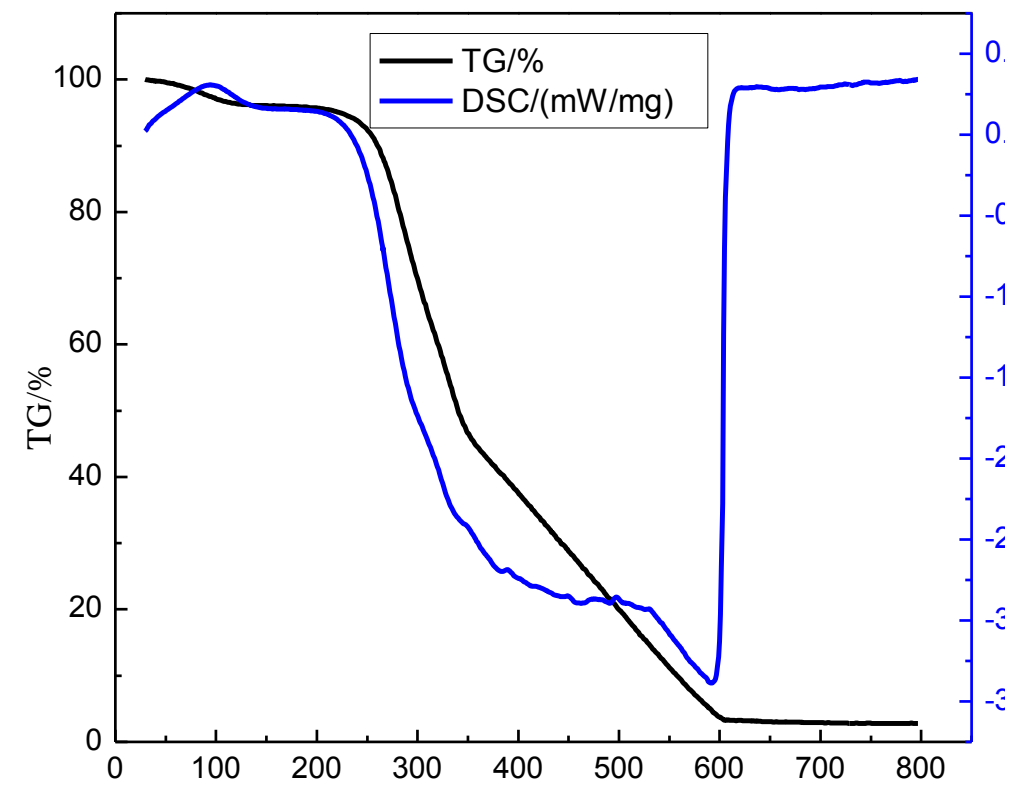

Fig. 1 TG-DSC curve of walnut shell

In the dehydration drying stage, internal water of sample leaked out, including mechanical water 
and chemosorption water, etc., accompanied by decompounding of a small amount of hemicellulose. Thus there is small endothermic peak at about $100^{\circ} \mathrm{C}$ on DSC curve. In the flash pyrolysis stage, the TG curve shows a rapid descent trend, and weight loss is about $60 \%$ in whole weight loss. This is the temperature interval with the most violent pyrolysis of walnut shell. Therefore thermal decomposition in this period is the most significant, and ends at about $350^{\circ} \mathrm{C}$. This is because the pyrolysis process of organic constituents such as cellulose, hemicellulose and a small amount of lignin in walnut shell superpose with each other, during which course, substantive heat is discharged. The stage of slow decompounding is slow decompounding and carbonization of residues. During this temperature interval, mainly the lignin continues to decompound. A great deal of volatile gas is generated, and hydrogen and oxygen continue to be eliminated, to make charcoal structure become more integral. This course is from about $350^{\circ} \mathrm{C}$ to temperature of completion of about $600{ }^{\circ} \mathrm{C}$, and weight loss is about $35 \%[4,5]$. Thus the walnut has been completely pyrolysed before reaching foaming temperature and fusing temperature of ceramic material, instead of influencing sintering.

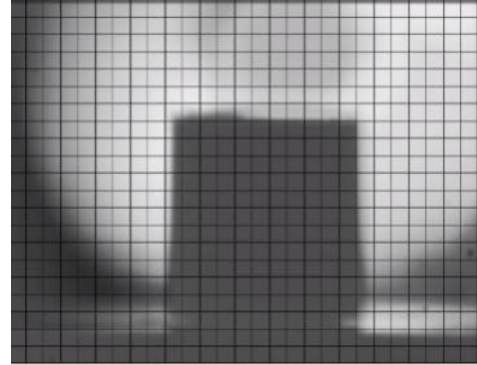

(a) $1100^{\circ} \mathrm{C}$

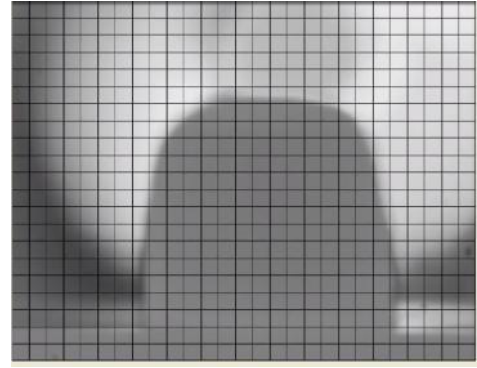

(c) $1195^{\circ} \mathrm{C}$

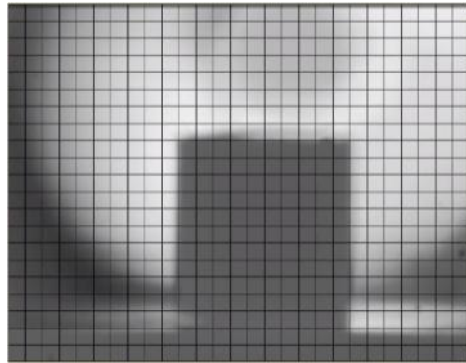

(b) $1150^{\circ} \mathrm{C}$

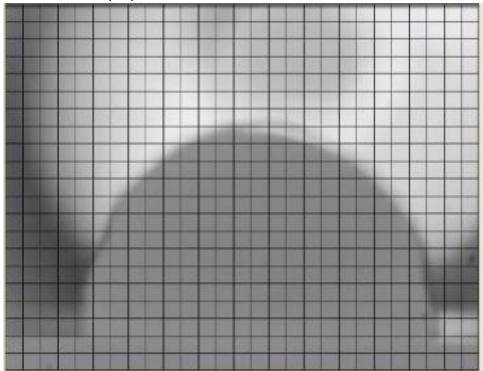

(d) $1235^{\circ} \mathrm{C}$

Fig. 2 Shale sintering image

Analyze sintering image of shale with proportion accounting for $90 \%$ of gross raw materials. Place sample of shale with size of about $\Phi 2 \times 6 \mathrm{~mm}$ in molybdenum filament tube type resistance furnace to be heated at an increasing temperature. The heating scope is $30-1400^{\circ} \mathrm{C}$ and heating rate is $10^{\circ} \mathrm{C} / \mathrm{min}$. The parallel rays from condenser project sample to magnifier through melting chamber, then the projection is transmitted to computer through CCD camera. Intercept image at different temperature nodes, which is shown in figure 2. Figure (b) shows sample volume shrinks to some extent at $1150{ }^{\circ} \mathrm{C}$, which is maybe because the shale begins to decompound and precipitate out other mineral facies. At $1195^{\circ} \mathrm{C}$, fillet appears on sample, indicating shale begins to fuse and liquidoid appears. At $1235^{\circ} \mathrm{C}$, molten state is obvious, and overt "drips" appear. By this time, shale basically completes decompounding of mineral facies and silicic acid reaction and new mineral facies are formed.

Thus, we can conclude that sintering temperature of ceramic material is about $1200^{\circ} \mathrm{C}$. The pyrolysis process of combining walnut shell and $\mathrm{SiC}$ foaming need temperature. to slowly heat up. The final temperature curve is shown in figure 3 . From room temperature to $650^{\circ} \mathrm{C}$, the heating rate is $10^{\circ} \mathrm{C} / \mathrm{min}$, and time is $1 \mathrm{~h}$. At $650^{\circ} \mathrm{C}$ to $1200^{\circ} \mathrm{C}$, heating rate is $6{ }^{\circ} \mathrm{C} / \mathrm{min}$, and time is $1.5 \mathrm{~h}$. Heat insulation time is $0.5-1 \mathrm{~h}$. In annealing stage, temperature is $1200^{\circ} \mathrm{C}$ to $800^{\circ} \mathrm{C}$, time is $0.5 \mathrm{~h}$. At $800^{\circ} \mathrm{C}$ to $60^{\circ} \mathrm{C}$, time is $4-10 \mathrm{~h}$. 


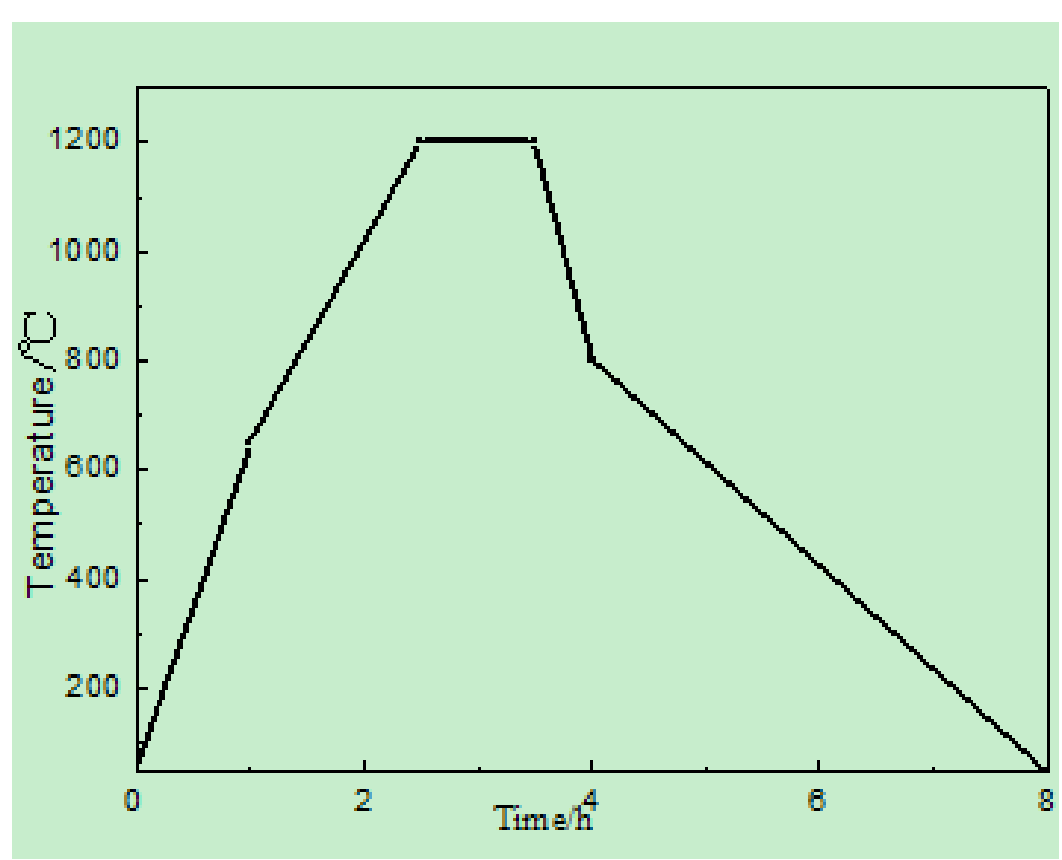

Fig. 3 Firing curve

\section{Effect of Walnut Shell Content on Properties of Products}

To find out the influence of walnut shell content on sintering, mixed contrasting sample of walnut was $10 \%$ of total mass of sample. Adopting above processes and defined temperature curve, samples were sintered and annealed, then sample properities was measured, shown in table 3. Table 3 shows that with increase of walnut quantity mixed into sample, volume density of samples increases, and flexural strength and compressive strength increase too. The density of product with $10 \%$ walnut mixed into is $180 \mathrm{~kg} / \mathrm{m}^{3}, 18 \%$ larger than blank sample, and flexural strength and compressive strength are respectively 1.031 $\mathrm{MPa}$ and $0.862 \mathrm{MPa}, 35 \%$ and $37 \%$ larger than blank sample. The reason to explain this is the mixture of walnut occupies and substitutes part of volume of ceramic material, which raises density of samples, thereby increasing density. As the larger the volume density is, the smaller the product's porosity is. The presence of pores decreases sectional area carrying load on the one hand, on the other hand, causes stress concentration to result in strength degradation [11], hence improvement on resist compression and folding strength.

In the meanwhile, after walnut shell is mixed into, as the content of fixed carbon in walnut itself reaches $15 \%$, leading to liberation of a great deal of $\mathrm{CO}$ and $\mathrm{CO}_{2}$ gases in sintering process, making sample's bubble structuremostly open pores, which increases water absorptivity of sample. In addition, the increase of the phenomenon of hybrid pores in sample with walnut mixed has a direct influence on heat-insulating property of product, so coefficient of thermal conductivity reduces to some extent [12].

Tab. 3 Properities of samples with different walnut shell contents

\begin{tabular}{cccccc}
\hline $\begin{array}{c}\text { Walnut shell } \\
\text { content }\end{array}$ & $\begin{array}{c}\text { Density } \\
\left(\mathrm{kg} / \mathrm{m}^{3}\right)\end{array}$ & $\begin{array}{c}\text { Flexural } \\
\text { strength } \\
(\mathrm{MPa})\end{array}$ & $\begin{array}{c}\text { Compressive } \\
\text { strength } \\
(\mathrm{MPa})\end{array}$ & $\begin{array}{c}\text { Thermal } \\
\text { conductivity } \\
\mathrm{W} /(\mathrm{m} \cdot \mathrm{K})\end{array}$ & $\begin{array}{c}\text { Water } \\
\text { absorption }\end{array}$ \\
\hline 0 & 152 & 0.762 & 0.631 & 0.064 & 1.18 \\
\hline $10 \%$ & 180 & 1.031 & 0.862 & 0.076 & 1.5 \\
\hline
\end{tabular}




\section{Microscopic Analysis}

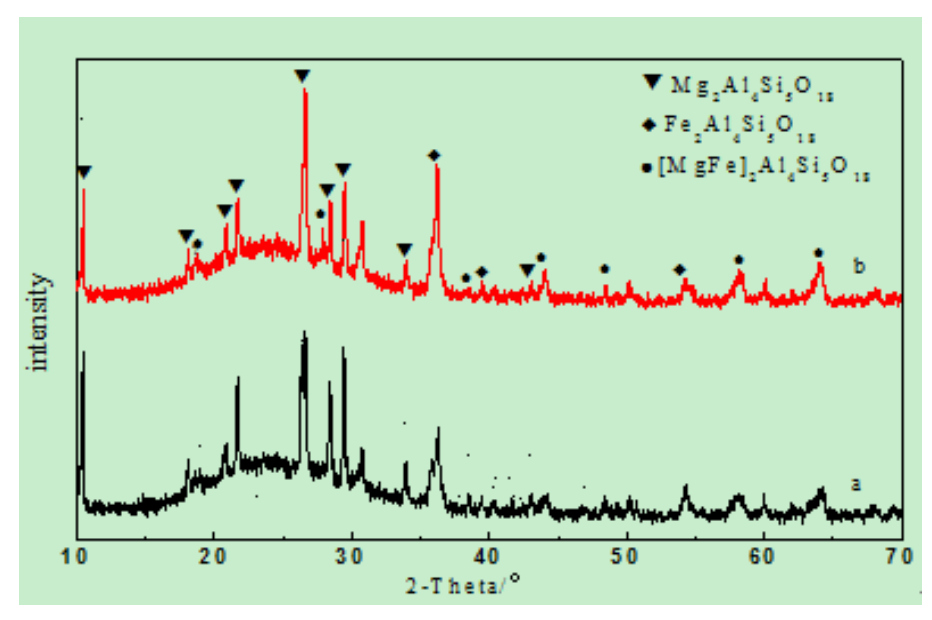

Fig. 4 XRD patterns of samples with different walnut shell contents

Fig. 4 reflects crystal shape of sintered product with different walnut quantities mixed into. The main crystalline phases of the two products are cordierite $\left(2 \mathrm{MgO} \cdot 2 \mathrm{Al}_{2} \mathrm{O}_{3} \cdot 5 \mathrm{SiO}_{2}\right)$, sekaninaite $\left(2 \mathrm{FeO} \cdot 2 \mathrm{Al}_{2} \mathrm{O}_{3} \cdot 5 \mathrm{SiO}_{2}\right)$ and a small amount of cordierite solid solution with $\mathrm{Mg} / \mathrm{Fe}$ codoped. And angles of diffraction peaks shown by the phases of the two samples are all the same, indicating mixing of walnut shell as a pore forming agent does not influence crystallization of sample. $\mathrm{SiO}_{2}$ in cordierite is mainly from $\mathrm{SiO}_{2}$ in shale and feldspar in raw material and $\mathrm{SiO}_{2}$ generated by $\mathrm{SiC}$ reaction. The potash feldspar graduates away due to decompounding and fusion [13]. When the temperature is up to $1200{ }^{\circ} \mathrm{C}, \mathrm{K}\left[\mathrm{AlSi}_{3} \mathrm{O}_{8}\right]$ crystalline phase hardly exists. Figure 5 shows appearance of sintered products with different quantity of walnut mixed into. The firing temperature of sample is $1200^{\circ} \mathrm{C}$. In the interior of clay body, there are obvious and even bubbles, as at this temperature, liquidoid viscosity reduces, while carborundum oxygenation is enhanced, producing more $\mathrm{CO}_{2}$ which is further discharged at a quicker rate [14]. While figure 5 (b) shows that after walnut shell is mixed into, the phenomenon of miscellaneous porosity increases and pores become open pores, leading increase of water absorptivity of sample and coefficient of thermal conductivity.

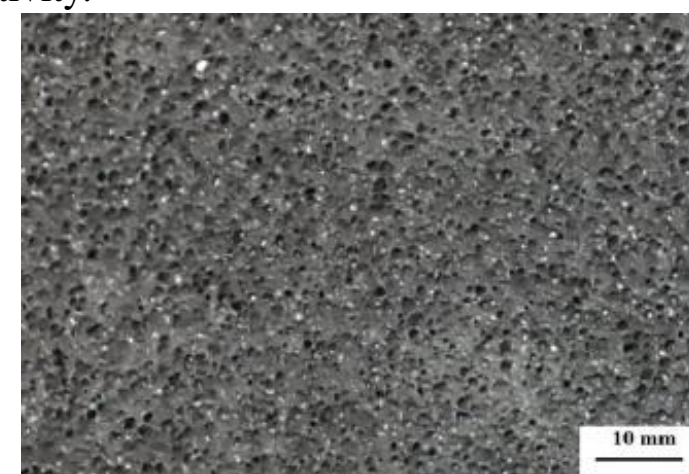

(a) $0 \%$

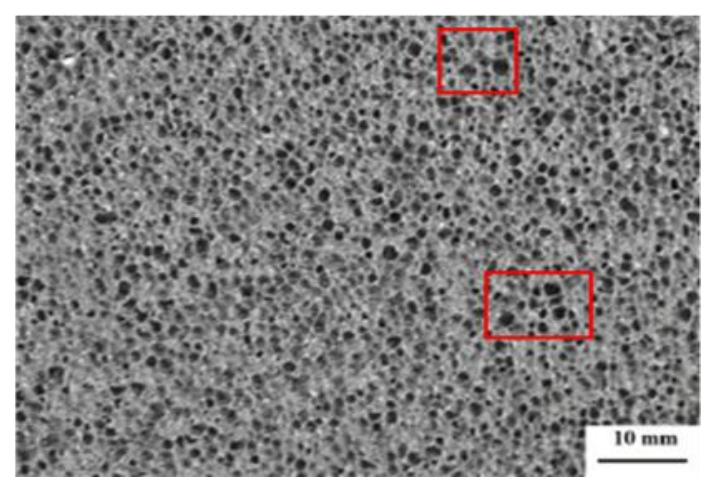

(b) $10 \%$

Fig. 5 Morphology of samples with different walnut shell contents

\section{Conclusions}

In this paper, the porous thermal insulation material with excellent performance was prepared with the help of high temperature foaming by adding silicon carbide as foaming agent and using the shale and feldspar as matrix material after a quality ratio of walnut shell was selected as a pore-forming agent

(1) According to the thermal history of shale and walnut shell, the firing curve could be acquired. From room temperature to $650^{\circ} \mathrm{C}$, the heating rate is $10^{\circ} \mathrm{C} / \mathrm{min}$. From $650^{\circ} \mathrm{C}$ to $1200^{\circ} \mathrm{C}$, heating rate 
is $6{ }^{\circ} \mathrm{C} / \mathrm{min}$ and the soak time is about $0.5-1 \mathrm{~h}$ at $1200{ }^{\circ} \mathrm{C}$. In annealing stage, temperature is from $1200^{\circ} \mathrm{C}$ to $800^{\circ} \mathrm{C}$ and the time is $0.5 \mathrm{~h}$. From $800^{\circ} \mathrm{C}$ to $60^{\circ} \mathrm{C}$, time is $4-10 \mathrm{~h}$.

(2) Based on the effect of walnut shell content on the properties of the sample,thedensity of the samplewith $10 \%$ walnut shellis $180 \mathrm{~kg} / \mathrm{m}^{3}$, increasing by $62 \%$ compared to the blank samples. Flexural strength and compressive strength are $1.031 \mathrm{MPa}$ and $0.862 \mathrm{MPa}$ respectively, which increase by $35 \%$ and $37 \%$ compared to the blank samples. As the larger the volume density is, the smaller the product's porosity is, which reduces the intensity of the stress concentration.

(3) According to the micro analysis of sintered products, XRD analysis shows thatmixing of walnut shell as a pore forming agent has no influence on the crystallization of sample. The main crystalline phases are cordierite $\left(2 \mathrm{MgO} \cdot 2 \mathrm{Al}_{2} \mathrm{O}_{3} \cdot 5 \mathrm{SiO}_{2}\right)$ and sekaninaite $\left(2 \mathrm{FeO} \cdot 2 \mathrm{Al}_{2} \mathrm{O}_{3} \cdot 5 \mathrm{SiO}_{2}\right)$. The micro-topography shows that the incorporation of walnut shell will lead to the phenomenon of miscellaneous porosity and the number of open pores increased, which leads the increase of water absorptivity of sample and coefficient of thermal conductivity.

\section{Acknowledgement}

Project Source: "12th Five-Year" rural construction area of national science and technology project Number: 2014BAL03B01-04.

\section{References}

[1] W. W. Qin, L. Zhang. The Technology of Comprehensive Utilization of Walnut Shell in China[J]. The Food Industry, 2012 Vol.33(11):138-140.

[2] Q. J. Wang. Comprehensive utilization of walnut shell [J]. Farm Products Processing, 2008 (1): 22-23.

[3] B. L. Zhang, J. H. Peng, X. X. Fan, etc. A reviewon multipurpose utilization techniques from walnut shells [J]. Journal of Chemical Industry of Forest Products (Bimonthly), 2003 (2): 21-25.

[4] Z. F. Zheng, J. C. Zou, B. Hua, etc. Studyon the constituents of walnut shell [J]. Journal of Southwest Forestry College, 2006 (2): 33-36.

[5] X. Y. Jiang, Y. Y. Liao, Z. Guo, etc.Pyrolysis characteristics and correlation anysis with the major components of seven kinds of nutshell[J]. Scientia Silvae Sinicae, 2015, Vol.51 (12): 79-86.

[6] L. W. Hu, G. H. Hou.Development prospect of energy saving thermal insulation material industry[J]. China New Technologies and Products, 2010 (16): 147.

[7] B. X. Zhou. Application prospect of inorganic insulation materials in exterior wall thermal insulation system[J]. Sichuan Building Science, 2013, 39 (01): 203-205.

[8] L. S. Zhang, Y. B. Qiu. High Temperature Foamed Ceramic and Its Application[J]. New Building Materials, 2005, (05): 58-59

[9] Harris RCA. Oxidation of 6H- alpha silicon- carbideplatelets[J]. Am. Ceram. Soc. 1975, 58(1- 2), 7.

[10] Vaughn, Wallace L., Maahs, Howard G. Active-to-passive transition in the oxidation of silicon car-bide and silicon nitride in air [J]. Am. Ceram. Soc.1990, 73(6), 1540.

[11] S. K. Liu. Ceramic Technology[M].Guangzhou: South China University of Technology Press, 1990: 142

[12] W. Xu, S. B. Sun, Y. L. Tian.Study on the raw materials composing and firing system for lightweight

[13] external wall brick[J]. Block-Brick-Tile, 2007 (10): 13-15.

[14] Luthra K L. Some new perspectives on oxidation ofsilicon- carbide and silicon- nitride [J]. Am. Ceram.Soc. 1991, 74(5), 1095.

[15] X. Li, S. B. Sun, Y. L. Tian. The influence of molding way on foam ceramic's physical performance[J]. China Ceramics, 2010, Vol.46 (10): 54-55+65. 